\title{
Genetic improvement of Ilex paraguariensis in western Santa Catarina State: estimate of phenotypic and genetic parameters
}

Melhoramento genético de Ilex paraguariensis para o oeste do Estado de Santa Catarina: estimativa de parâmetros fenótipos e genéticos

Mejoramiento de Ilex paraguariensis para el oeste del Estado de Santa Catarina: estimación de parámetros fenotípicos y genéticos

Received: 01/24/2022 | Reviewed: 02/01/2022 | Accept: 02/05/2022 | Published: 02/09/2022

Paulo Alfonso Floss

ORCID: https://orcid.org/0000-0003-3476-7325 Empresa de Pesquisa Agropecuária e Extensão Rural de Santa Catarina, Brazil E-mail: pfloss@epagri.sc.gov.br

Carlos André Stuepp

ORCID: https://orcid.org/0000-0003-4651-9249 Universidade Estadual de Ponta Grossa, Brazil E-mail: castuepp@uepg.br

Ivar Wendling

ORCID: https://orcid.org/0000-0002-1008-6755

Embrapa Florestas, Brazil

E-mail: ivar.wendling@embrapa.br

Vânia Beatriz Cipriani

ORCID: https://orcid.org/0000-0001-5036-0811

Universidade Federal Paraná, Brazil

E-mail: vania.cipriani@ufpr.br

Cristiane Aparecida Fioravante Reis

ORCID: https://orcid.org/0000-0003-3109-8277 Embrapa Florestas, Brazil

E-mail: cristiane.reis@embrapa.br

\begin{abstract}
An especially important species in South America, yerba mate (Ilex paraguariensis A.St.-Hil) is traditionally consumed as tea, chimarrão and tererê. Due to the formation of mate plantations with low productivity and high heterogeneity, genetic improvement actions have been conducted as a way to generate more productive cultivars of this species. In this sense, the present study aimed to estimate phenotypic and genetic parameters of yerba mate production traits earlier in provenance and progeny tests, implanted in the municipalities of Chapecó and Guatambu, in the western region of Santa Catarina State (South America). In each environment, 55 open pollinated yerba mate progenies were evaluated in a randomized complete block design, with five replications and three plants per plot. The traits measured at two years old were: height and crown diameter $(\mathrm{m})$ and at three years were: visually estimated commercial biomass, weighed commercial biomass and thick branch mass $(\mathrm{kg})$. The data obtained was analyzed using the genetic-statistical Selegen software. The results obtained support that there is genetic variability in the open pollinated yerba mate progenies evaluated in Santa Catarina, with possible gains by selecting the best parent trees for future production of improved seeds and for cloning.
\end{abstract}

Keywords: Growth traits; Progenies x environments interaction; Progeny test; South of Brazil.

\section{Resumo}

Espécie de grande importância na América do Sul, a erva-mate (Ilex paraguariensis) é ingerida tradicionalmente na forma de chás, chimarrão e tererê. Com a formação de ervais com produtividades abaixo do esperado e alta heterogeneidade, ações de melhoramento genético da espécie têm sido conduzidas como forma de contribuir com a geração de cultivares mais produtivas. Neste sentido, o presente estudo objetivou a estimativa precoce de parâmetros fenotípicos e genéticos para caracteres de produção de erva-mate em teste de procedências e progênies, implantado nos municípios de Chapecó e Guatambu, na região oeste do Estado de Santa Catarina (América do Sul). Em cada ambiente foram avaliadas 55 progênies de polinização aberta, no delineamento de blocos completos casualizados, com cinco repetições e três plantas por parcela. As características mensuradas, aos dois anos de idade, foram: altura e diâmetro de copa, em metros e, aos três anos: biomassa comercial aferida visualmente, biomassa comercial aferida em balança e massa de galhos grossos, em quilogramas. Os dados obtidos foram analisados no software genéticoestatístico Selegen. Os resultados obtidos permitem inferir que há variabilidade genética nas progênies de polinização 
aberta de erva-mate, avaliadas em Santa Catarina, com possibilidades de ganhos com a seleção futura das melhores árvores como genitoras para produção de sementes melhoradas e, também, para clonagem.

Palavras-chave: Características de crescimento; Interação progênies x ambientes; Teste de progênie; Sul do Brasil.

\section{Resumen}

Especie de gran importancia en Suramérica, la yerba mate (Ilex paraguariensis) se ingiere tradicionalmente en forma de té, mate y tererê. Con la formación de hierbas con rendimientos menores a los esperados y alta heterogeneidad, se han realizado acciones de mejoramiento genético de la especie como forma de contribuir a la generación de cultivares más productivos. En ese sentido, el presente estudio tuvo como objetivo la estimación temprana de parámetros fenotípicos y genéticos para caracteres de producción de yerba mate en un ensayo de procedencia y progenie, implementado en los municipios de Chapecó y Guatambu, en la región occidental del Estado de Santa Catarina (Suramérica). En cada ambiente se evaluaron 55 progenies de polinización libre, en un diseño de bloques completos al azar, con cinco repeticiones y tres plantas por parcela. Las características medidas, a los dos años de edad, fueron: altura y diámetro de copa, en metros, ya los tres años: biomasa comercial medida visualmente, biomasa comercial medida a escala y masa de ramas gruesas, en kilogramos. Los datos obtenidos se analizaron mediante el software genético-estadístico Selegen. Los resultados obtenidos permiten inferir que existe variabilidad genética en las progenies de polinización abierta de yerba mate, evaluadas en Santa Catarina, con posibilidades de ganancias con la futura selección de los mejores árboles como progenitores para la producción de semillas mejoradas y también para clonación.

Palabras clave: Características de crecimiento; Interacción progenies x ambientes; Prueba de descendência; Sur de Brasil.

\section{Introduction}

Yerba mate (Ilex paraguariensis A.St.-Hil.) has significant economic, environmental and cultural importance in South America due to its traditional consumption as tea, chimarrão and tererê (Sturion \& Resende 2010; Paiva et al. 2020). Its natural occurrence area covers parts of Argentina, Brazil, Paraguay and Uruguay (Sturion \& Resende, 2010). In 2018, Brazilian yerba mate production totaled 939,580 tons, with approximately $42 \%$ originating from native plants and $58 \%$ from plantations (IBGE, 2018). Yerba mate is recognized as the most important non-timber forest product in the Southern Region of Brazil.

In Brazil, from the 1980s, actions were initiated to implement mate plantations, mainly due to the agricultural expansion over areas of native forest formations and the increased consumption of yerba mate (Sturion \& Resende, 2010). Certain aspects such as using seedlings with questionable genetic quality and the gap between appropriate management technology and its adoption by professionals and rural producers have led to varied results, with average Brazilian productivity of $7.59 \mathrm{t} \mathrm{ha}^{-1}$ (IBGE, 2018).

To achieve better productivity, genetic improvement programs have been developed for yerba mate in Brazil since the 1990s. With the objective of obtaining genetically superior seeds and clones, emphasis has been put on selecting traits of adaptation, leaf mass production, resistance to diseases and pests, defoliation, and crown architecture (type of branching) (Sturion \& Resende, 2010). Such programs, conducted by the Brazilian Agricultural Research Company (Embrapa) and the Agricultural Research and Rural Extension Company of Santa Catarina (Epagri), have relied on the evaluation of provenances and progenies of open pollinated yerba mate in various locations, that is, base populations (Sturion \& Resende, 2010). Previously selected clones are also being evaluated under contrasting environmental conditions within the area of yerba mate cultivation in the Southern Region.

Yerba mate trees should be selected based on their additive genetic value when the objective is to produce improved seeds, and their genotypic value when the purpose is to select candidate trees for cloning (Resende \& Barbosa, 2005). In order to rank the best trees, such selection must be accurate and executed when a tree is close to its exploitation age. However, selecting yerba mate trees based on leaf weight is extremely laborious, especially from the fourth year onwards, as it involves pruning each tree, removing leaves and thinning branches (up to $7 \mathrm{~mm}$ ), and then weighing them (Wendling et al., 2016, 
2018). Indirect methods to evaluate yerba mate plant production can be interesting alternatives for the genetic improvement of the species, mainly because they can reduce evaluation time and, consequently, reduce expenses related to the activity (Sturion et al., 2017).

Based on these considerations, the present study aimed at early recognition of phenotypic and genetic parameters for yerba mate production traits from provenance and progeny tests implanted in the Chapecó and Guatambu municipalities, in western Santa Catarina State in Brazil, South America.

\section{Methodology}

The evaluated genetic material consisted of 55 open pollinated I. paraguariensis progenies. This germplasm is composed of 32 second generation progenies, selected from a provenance and progeny test implanted in 1997 in the Chapecó National Forest, in Guatambu, Santa Catarina, and 23 first, second and third generation progenies selected by Embrapa Floresta's from different locations in Southern Brazil.

The experiments were carried out in two environments: one in an area of the Chapecó National Forest (Flona), in the municipality of Guatambu ( $27^{\circ} 06^{\prime} 33^{\prime \prime} \mathrm{S}$ and $\left.52^{\circ} 47^{\prime} 35^{\prime \prime} \mathrm{W}, 603 \mathrm{~m}\right)$, and another in an area of the Agricultural Research and Rural Extension Company of Santa Catarina/ Family Agriculture Research Center (Epagri/Cepaf), in the municipality of Chapecó $\left(27^{\circ} 05^{\prime} 17^{\prime \prime} \mathrm{S}\right.$ and $\left.52^{\circ} 37^{\prime} 56^{\prime \prime} \mathrm{W}, 675 \mathrm{~m}\right)$, both in Santa Catarina State, South America. Predominantly Dystrophic Red Latosol soils are found at both sites.

The Flona area was previously occupied by a Pinus sp. plantation, with 45 -year rotation. The Epagri/Cepaf area was previously occupied with annual crops. The two areas are located $15 \mathrm{~km}$ apart, with similar climatic characteristics, such as average annual rainfall around 2,000 $\mathrm{mm}$ and subtropical climate (Cfa) with hot summers and infrequent frosts, and welldistributed rainfall throughout the year (Figure 1). The average temperature of the hottest months is $>22^{\circ} \mathrm{C}$ and the average of the coldest months is $<18^{\circ} \mathrm{C}$, with average annual temperature ranging between $18^{\circ} \mathrm{C}$ and $19^{\circ} \mathrm{C}$.

Each experiment was implemented using a completely randomized block design, with five replicates and plots containing three plants. Area preparation involved marking lines with subsoiler at $50 \mathrm{~cm}$ depth. Manual planting occurred in July 2016, with $3.0 \mathrm{~m}$ x $1.5 \mathrm{~m}$ spacing. The first fertilizations were performed six months after planting (January 2017). These fertilizations were done according to the recommendations of Santin e Wendling (2017) and performed twice a year (January and September). All fertilizations were the same until the first commercial leaf mass pruning/harvesting. 
Figure 1. Distribution of the monthly rainfall and temperature averages from January to December, for the municipalities of Chapecó and Guatambu, located in Santa Catarina State.

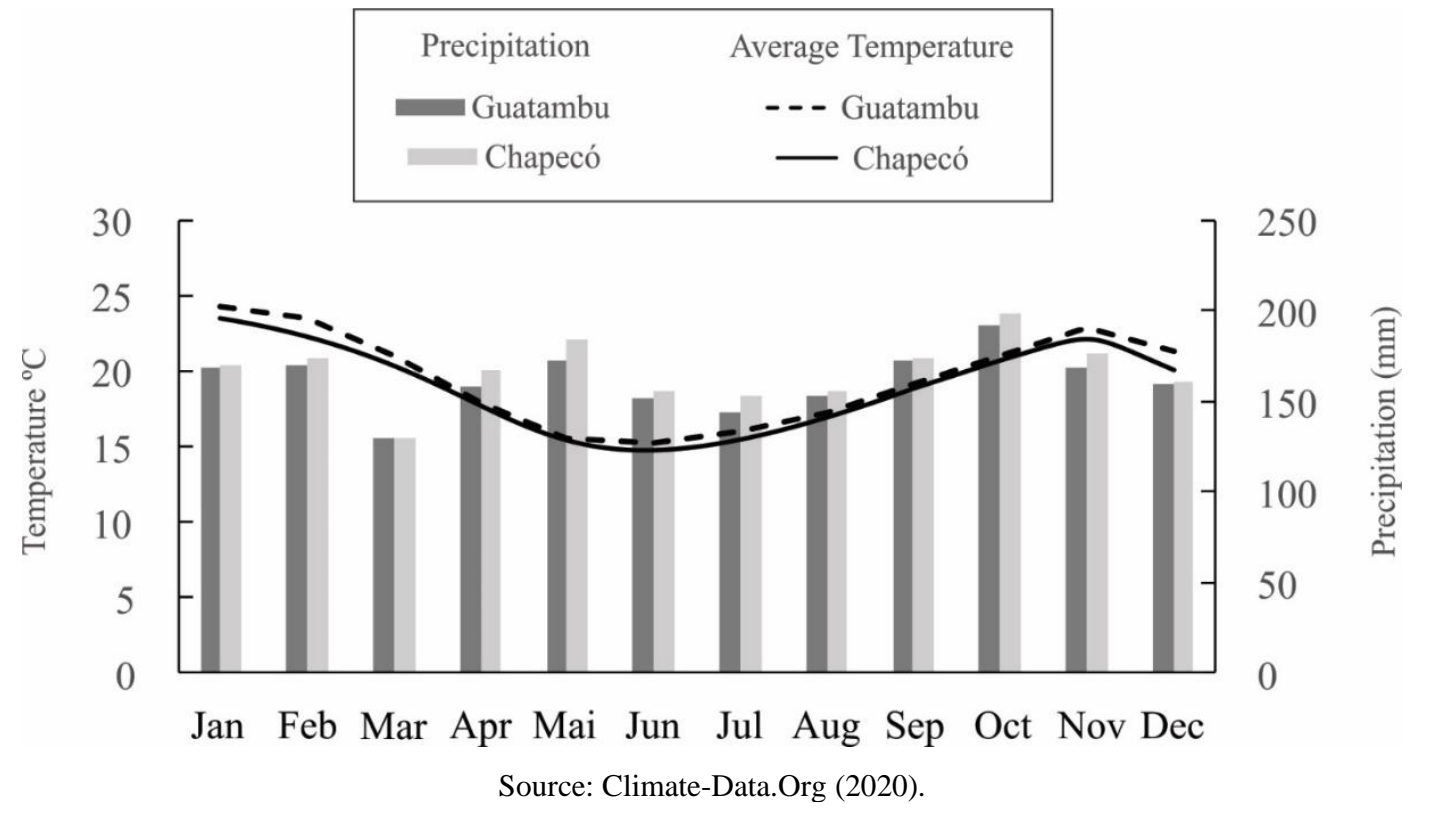

After planting, seedlings were protected from sunlight using strips of wood according to the usual protocol for this crop. The post-planting crop treatments consisted of mechanized mowing between rows at 60, 120 and 180 days and at six, 12 and 18 months after planting. Three re-plantings were performed, the last of which occurred in September 2017, as some plants were affected by frosts in July and August 2017.

At two years old (July/2018), the height (m) and crown diameter (m) were measured with a graduated ruler. At three years old (July/2019), the individual commercial biomass of all plants was evaluated through indirect or visual estimates, indicating an estimated value of commercial productivity (commercial biomass in $\mathrm{kg}$ ) for each plant, which was evaluated from the experience and previous training of an evaluator according to the methodology proposed by Wendling et al. (2016). After measuring the productivity score, plants were harvested individually and their real biomass was directly measured on a suspended digital scale, and was divided into two components: commercial biomass (leaves and branches below $7 \mathrm{~mm}$, in $\mathrm{kg}$ ) and thick branch mass (branches over $7 \mathrm{~mm}$, in $\mathrm{kg}$ ). This procedure was performed on all living plants. However, the last three traits were not evaluated in some plants if they had reduced size in the first harvest.

For the analyzes of traits evaluated in each of the environments where the open pollinated yerba mate progeny test were implemented, the model 1 in Selegen REML/BLUP software was used (Resende, 2016), in which:

(I) $\quad \mathrm{y}=\mathrm{Xr}+\mathrm{Za}+\mathrm{Wp}+\mathrm{e}$,

Where y is the data vector, " $r$ " is the vector of fixed effects of repetition added to the general average, "a" is the vector of the random individual additive genetic effects, "p" is the vector of the random effects of plots and "e" is the vector of the random effects of errors or residues. For the joint analysis of environments, the model 4 was used:

$$
\mathrm{y}=\mathrm{Xr}+\mathrm{Za}+\mathrm{Wp}+\mathrm{Ti}+\mathrm{e}
$$

In which y is the data vector, " $r$ " is the vector of fixed effects of repetition added to the general average, "a" is the vector of the random individual additive genetic effects, "p" is the vector of the random effects of plots, "i " is the vector of the effects of progenies $\mathrm{x}$ environments interaction and " $\mathrm{e}$ " is the vector of the random effects of errors or residues. Capital letters represent the incidence matrices for respective effects. 
From these analyzes of unbalanced data, the significance of the random effects of the models was obtained from the likelihood ratio test (LRT) and the deviance analyses for each of the traits evaluated (Resende, 2016). Estimates of the selective accuracy and genetic and phenotypic parameters of the progenies were obtained for the environmental level and for the average of the environments.

\section{Results and Discussion}

Survival rates were $78 \%$ in Guatambu and $84 \%$ in Chapecó. Even with the three re-plantings, mortality was considerably high when compared to the 5\% recommendation for forest species traditionally planted in Brazil. Plantings for both experiments were carried out in July 2016, and the seedlings were adequately protected from the sun. Yerba mate is a climax species that is sensitive to sunlight, so much so that, even if previously rustified and adapted to sunlight, seedlings should be protected during or immediately after being planted in the field (Sturion \& Resende, 2010). Nevertheless, this factor was probably not the cause of such high seedling mortality.

The high mortality rate can partially be attributed to a period of low precipitation that occurred soon after planting, which lead to replanting due mortality from water stress. However, it should be noted that some progenies had a limited number of seedlings for replanting, which also affected the experimental survival rates. Additionally, there were severe frosts in the winter of 2017 and, although replanting was conducted (at 14 months old), the limited number of seedlings, along with the mortality of other plants over time, explain the high mortality rates. The Guatambu experiment suffered more from the frost when compared to Chapecó, which was clear from the survival rates of both environments.

Table 1 shows the estimated averages for the different traits evaluated in Guatambu and Chapecó. Even though the Guatambu experiment presented the lowest survival rate, it presented the highest averages for all evaluated traits, being approximately $4 \%$ higher in crown diameter, $10 \%$ in height, $39 \%$ in visually estimated commercial biomass, $74 \%$ in weighed commercial biomass and $82 \%$ in thick branch mass. These results can be explained by differences in the soil qualities in the experiments, as these soils present integrated physical, chemical and biological properties (Srivastava et al., 2019). When converting natural areas into pine forests, these properties are modified, increasing the content and stabilization of organic carbon in the soil that is strongly influenced by rotation (Pfleger et al., 2017). This seems to be the most plausible explanation for the different averages for the experiments herein, since the Guatambu area was previously occupied by a Pinus $s p$. plantation with extensive rotation, while the Chapecó area was occupied by annual crops.

Table 1. Estimated averages of the traits crown diameter $(\mathrm{m})$, height $(\mathrm{m})$, visually estimated biomass (kg), weighed biomass $(\mathrm{kg})$ and thick branch mass $(\mathrm{kg})$ evaluated per plant, in a ta open pollinated Ilex paraguariensis (yerba mate) progenies test from two municipalities in Santa Catarina.

\begin{tabular}{|c|c|c|}
\hline \multirow{2}{*}{ Traits } & \multicolumn{2}{|c|}{ Average estimates } \\
\hline & Guatambu/SC & Chapecó/SC \\
\hline Crown diameter $(\mathrm{m})$ & $0.48(642-78 \%)^{*}$ & $0.46(694-84 \%)^{*}$ \\
\hline Height (m) & $0.97(642-78 \%)^{*}$ & $0.88(694-84 \%)^{*}$ \\
\hline Visually estimated biomass (kg) & $1.68(611-74 \%)^{*}$ & $1.21(641-78 \%)^{*}$ \\
\hline Weighed biomass (kg) & $2.23(600-73 \%)^{*}$ & $1.28(637-77 \%)^{*}$ \\
\hline Thick branch mass $(\mathrm{kg})$ & $0.82(511-62 \%)^{*}$ & $0.45(532-64 \%)^{*}$ \\
\hline
\end{tabular}

* In parentheses are the number of individuals evaluated and their percentage in relation to the total number of planned plants for each trait and evaluation environment. Source: Authors. 
The average estimate of commercial biomass productivity (mass of leaves and thin branches $<7$ mm) based on visual estimation, was underestimated by approximately 25\% in Guatambu and 5\% in Chapecó compared to the biomass measured on a scale. Visual estimation is a low-cost alternative that requires less work to qualitatively define the production of individuals (Teixeira et al., 2020). However, its efficiency is strongly related to the traits of high heritability, as well as to the degree of training of the evaluator. For yerba mate, visual selection is commonly used to select matrix plants in seed collection areas. As the degree of difficulty in obtaining accurate estimates of commercial biomass with a scale greatly increases with the age of yerba mate experiments, investing in constant training of evaluators and in experimental quality seem to be the most plausible ways to maximize the selection accuracy of this trait.

The estimates of selective accuracy for the traits evaluated in Guatambu were considerably high (above 71\%), except for thick branch mass (Table 2). However, in Chapecó, accuracies stayed below 66\%, with critical values for visually estimated commercial biomass, weighed commercial biomass and thick branch mass. In general, accuracy values greater than $70 \%$ are desirable in genetic improvement experiments, since accuracy informs about the effectiveness of the inference for genotypic value (value of cultivation and use) and, consequently, about the correct ordering of genetic materials for selection purposes (Resende \& Duarte, 2007). The mortality rate, differences in tree performance due to replanting, genetic variability and/or the number of repetitions equal to fifteen per environment may have influenced these results, since the ideal number of repetitions recommended for experiments with forest species is 30+ (Resende \& Barbosa, 2005). 


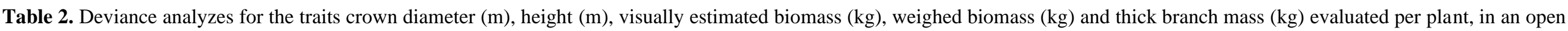
pollinated Ilex paraguariensis (yerba mate) progenies test from two municipalities in Santa Catarina.

\begin{tabular}{|c|c|c|c|c|c|c|c|c|c|c|}
\hline \multirow{3}{*}{ Sources of Variation } & \multicolumn{10}{|c|}{ Traits } \\
\hline & \multicolumn{2}{|c|}{ Crown Diameter } & \multicolumn{2}{|c|}{ Height } & \multicolumn{2}{|c|}{ Visually estimated biomass } & \multicolumn{2}{|c|}{ Weighed biomass } & \multicolumn{2}{|c|}{ Thick branch mass } \\
\hline & Deviance & $\mathrm{LRT}^{1}$ & Deviance & LRT $^{1}$ & Deviance & LRT $^{1}$ & Deviance & LRT $^{1}$ & Deviance & LRT $^{1}$ \\
\hline Progenies $^{+}$ & $-1,002.39$ & $26.96^{*}$ & -402.40 & $19.54 *$ & 886.65 & $8.59 *$ & $1,306.20$ & $12.88^{*}$ & 186.50 & $1.70^{\mathrm{ns}}$ \\
\hline Plots $^{+}$ & $-1,024.35$ & $5.00 *$ & -416.84 & $5.10 *$ & 888.39 & $10.33^{*}$ & $1,300.89$ & $7.57 *$ & 201.86 & $17.06^{*}$ \\
\hline \multirow[t]{2}{*}{ Accuracy (\%) } & \multicolumn{2}{|c|}{82.89} & \multicolumn{2}{|c|}{79.83} & \multicolumn{2}{|c|}{71.77} & \multicolumn{2}{|c|}{76.27} & \multicolumn{2}{|c|}{55.90} \\
\hline & \multicolumn{10}{|c|}{ Chapecó/SC } \\
\hline Sources of Variation & Deviance & $\mathrm{LRT}^{1}$ & Deviance & $\mathrm{LRT}^{1}$ & Deviance & $\mathrm{LRT}^{1}$ & Deviance & $\mathrm{LRT}^{1}$ & Deviance & $\mathrm{LRT}^{1}$ \\
\hline Progenies $^{+}$ & $-1,377.57$ & $6.96^{*}$ & -689.39 & $4.85^{*}$ & 308.65 & $0.35^{\mathrm{ns}}$ & 482.66 & $0.40^{\mathrm{ns}}$ & -476.94 & $0.03^{\mathrm{ns}}$ \\
\hline Plots $^{+}$ & $-1,354.57$ & $28.96^{*}$ & -660.17 & $34.87 *$ & 365.57 & $57.27 *$ & 549.42 & $67.16^{*}$ & -423.79 & $53.18 *$ \\
\hline Complete Model & $-1,384.43$ & - & -694.24 & - & 308.30 & - & 482.26 & - & -476.97 & - \\
\hline Accuracy (\%) & \multicolumn{2}{|c|}{66.51} & \multicolumn{2}{|c|}{62.43} & \multicolumn{2}{|c|}{36.79} & \multicolumn{2}{|c|}{37.89} & \multicolumn{2}{|c|}{18.16} \\
\hline
\end{tabular}


without these effects. Source: Authors. 
For the deviance analysis of the traits evaluated in Guatambu, significant effects of progenies were observed by the LRT test at 5\% probability, except for thick branch mass. For the Chapecó analyses, significant effects of progenies were only observed for crown diameter and height. Significant effects indicate that at least one of the progenies presents different behavior than the others for the trait considered, with possible gains in the selection process.

Estimates of phenotypic and genetic parameters for both environments are presented in Table 3. However, it should be noted that only parameters with significant effects in the deviance analysis are relevant. Estimates of additive genetic variance are useful for selecting parent plants for recurrent selection. Regarding the selection of superior trees for cloning, as seen herein, all genetic variation is available and is greater than the additive genetic variation, since this is already one of the components of genetic variation. 


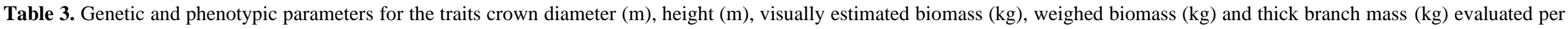
plant, in an open pollinated Ilex paraguariensis (yerba mate) progenies test from two municipalities in Santa Catarina.

Genetic and Phenotypic Paramenters Traits

\section{Environment: Guatambu/SC}

Additive genetic variance

Environmental variance between plots

Residual variance (environmental + non-additive)

Individual phenotypic variance

Individual inheritance restricted ${ }^{1}$

Plots coefficient

Average heritability of progênies

Individual additive genetic variation coefficient

Genotypic variation between progenies coefficient

Residual variation coefficient

Relative variation coefficient

Environment: Chapecó/SC

Additive genetic variance

Environmental variance between plot

Residual variance (environmental + non-additive)

Individual phenotypic variance

Individual inheritance restricted ${ }^{1}$

Plots coefficients

Average heritability of progênies

Individual additive genetic variation coefficient

Genotypic variation between progenies coefficient

Residual variation coefficient

Relative variation coefficient

\begin{tabular}{|c|c|c|c|c|}
\hline Crown diameter & Height & Visually estimated biomass & Weighed biomass & Thick branch mass \\
\hline 0.05 & 0.10 & 0.55 & 1.41 & 0.09 \\
\hline 0.01 & 0.02 & 0.24 & 0.42 & 0.13 \\
\hline 0.02 & 0.08 & 0.81 & 1.49 & 0.32 \\
\hline 0.08 & 0.20 & 1.60 & 3.32 & 0.54 \\
\hline $0.61(0.44-0.78)$ & $0.50(0.34-0.66)$ & $0.34(0.21-0.47)$ & $0.43(0.28-0.58)$ & $0.17(0.07-0.27)$ \\
\hline 0.09 & 0.10 & 0.15 & 0.13 & 0.24 \\
\hline 0.69 & 0.64 & 0.51 & 0.58 & 0.31 \\
\hline 44.79 & 32.50 & 44.21 & 53.19 & 36.91 \\
\hline 22.40 & 16.25 & 22.10 & 26.60 & 18.45 \\
\hline 33.80 & 27.41 & 47.95 & 50.42 & 61.21 \\
\hline 0.66 & 0.59 & 0.46 & 0.53 & 0.30 \\
\hline 0.01 & 0.03 & 0.05 & 0.07 & 0.01 \\
\hline 0.01 & 0.04 & 0.23 & 0.33 & 0.06 \\
\hline 0.03 & 0.07 & 0.37 & 0.47 & 0.10 \\
\hline 0.05 & 0.14 & 0.65 & 0.87 & 0.17 \\
\hline $0.29(0.17-0.41)$ & $0.25(0.14-0.36)$ & $0.07(0.01-0.13)$ & $0.08(0.02-0.14)$ & $0.02(-0.01-0.05)$ \\
\hline 0.23 & 0.25 & 0.36 & 0.38 & 0.37 \\
\hline 0.44 & 0.39 & 0.13 & 0.14 & 0.03 \\
\hline 26.95 & 21.09 & 17.64 & 20.30 & 11.19 \\
\hline 13.47 & 10.54 & 8.82 & 10.15 & 5.59 \\
\hline 33.83 & 29.50 & 49.85 & 55.42 & 67.72 \\
\hline 0.40 & 0.36 & 0.18 & 0.18 & 0.08 \\
\hline
\end{tabular}

${ }^{1}$ Confidence interval in parentheses. Source: Authors. 
In Guatambu, the environment with the best estimates of selective accuracy and significant effects of progenies for almost all traits, values of restricted individual heritability and average heritability of progenies were higher for the traits of crown diameter and height when compared to the other traits, indicating higher probabilities of gains with selection. The highest heritabilities are linked to higher estimates of genetic variance, as well as selective accuracy (Resende \& Duarte, 2007).

The values of the individual additive genetic variation coefficients were approximately twice as high as the coefficients of genotypic variation between progenies. Variability among individuals was higher than among progenies, which is a positive aspect for selecting better yerba mate trees, either for cloning or as parents for improved seed production.

On the other way, the estimates of the residual variation coefficients were remarkably high (above 30\%), being higher than the estimates of the individual additive genetic variation coefficients in some cases. The coefficient of variation estimates the precision of the experiment, depending only on the residual variation as a proportion of the experiment average (Lopes et al., 2021). Thus, in theory, the higher the coefficient estimate, the lower the precision of the experiment, or the worse the experimental quality. However, the measurement of experimental quality through selective accuracy is better than the residual variation coefficient, because it not only considers the magnitude of the residual variation, but also the number of repetitions and genetic control of the traits being evaluated (Malikousk et al., 2021). This aspect can be observed herein with high accuracy estimates obtained for traits with high coefficients of residual variation.

The values of relative variation coefficients were between 0.36 and 0.66 for traits with significant effects of progenies at the environmental level. Nevertheless, this coefficient does not consider the number of repetitions. In a publication about the accuracy and quality control of plant breeding experiments, Resende \& Duarte (2007) present a series of considerations about this topic, leading to the reflection that more repetitions should be performed in future yerba mate experiments. However, this does not mean that superior trees cannot be identified in the selection process of the progeny test.

In the joint deviance analysis of environments, no significant effects of progenies were observed by the LRT test (at $5 \%$ probability) for the traits crown diameter, height, visually estimated commercial biomass, weighed commercial biomass and thick branch mass for the present evaluation ages (Table 4). On the other hand, there were significant effects of plots in all cases. 
Research, Society and Development, v. 11, n. 3, e1711326084, 2022

(CC BY 4.0) | ISSN 2525-3409 | DOI: http://dx.doi.org/10.33448/rsd-v11i3.26084

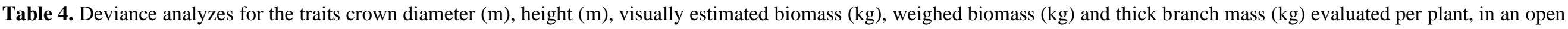
pollinated Ilex paraguariensis (yerba mate) test from two municipalities in Santa Catarina.

\begin{tabular}{|c|c|c|c|c|c|c|c|c|c|c|}
\hline \multirow{3}{*}{ Sources of Variation } & \multicolumn{10}{|c|}{ Traits } \\
\hline & \multicolumn{2}{|c|}{ Crown diameter } & \multicolumn{2}{|c|}{ Height } & \multicolumn{2}{|c|}{ Visually estimated biomass } & \multicolumn{2}{|c|}{ Weighed biomass } & \multicolumn{2}{|c|}{ Thick branch biomass } \\
\hline & Deviance & LRT $^{1}$ & Deviance & $\mathrm{LRT}^{1}$ & Deviance & $\mathrm{LRT}^{1}$ & Deviance & LRT $^{1}$ & Deviance & $\mathrm{LRT}^{1}$ \\
\hline Progenies $^{+}$ & $-2,384.20$ & $3.30^{\mathrm{ns}}$ & $-1,091.89$ & $1.58^{\mathrm{ns}}$ & $1,331.50$ & $0.73^{\mathrm{ns}}$ & $2,068.20$ & $0.17^{\mathrm{ns}}$ & -94.67 & $0.68^{\mathrm{ns}}$ \\
\hline Plots $^{+}$ & $-2,360.36$ & $27.14 *$ & $-1,063.26$ & $30.22 *$ & $1,373.35$ & $42.58^{*}$ & $2,101.33$ & $33.30^{*}$ & -44.84 & $50.51 *$ \\
\hline Progenies $\mathrm{x}$ environments & $-2,378.77$ & $8.73 *$ & $-1,085.97$ & $7.51^{*}$ & $1,333.96$ & $3.19^{\mathrm{ns}}$ & $2,076.70$ & $8.67 *$ & -95.09 & $0.26^{\mathrm{ns}}$ \\
\hline Accuracy $(\%)$ & \multicolumn{2}{|c|}{64.00} & \multicolumn{2}{|c|}{55.36} & \multicolumn{2}{|c|}{47.31} & \multicolumn{2}{|c|}{32.55} & \multicolumn{2}{|c|}{48.82} \\
\hline Gentic correlation between environments & \multicolumn{2}{|c|}{0.42} & \multicolumn{2}{|c|}{0.33} & \multicolumn{2}{|c|}{0.30} & \multicolumn{2}{|c|}{0.11} & \multicolumn{2}{|c|}{0.54} \\
\hline
\end{tabular}

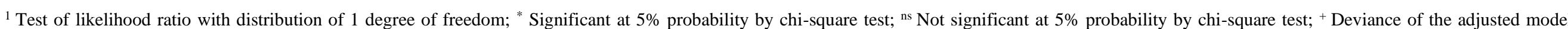
without these effects. ${ }^{2}$ Correlation of the average performance of progenies between the two aforementioned environments. Source: Authors. 
There were significant effects of the interaction progenies $\mathrm{x}$ environments for the traits crown diameter, height and weighed commercial biomass according to the LRT test, at 5\% probability. The presence of interaction reflects the uncoincidental behavior of the progenies in the two environments where these traits were evaluated. In both environments, the low correlation estimates between the average performance of progenies for all evaluated traits corroborate these results. The difference in fertility between soils is probably the factor that most influenced these results. Furthermore, the accuracy values of the joint analyses of environments were below ideal for genetic improvement experiments (Resende \& Duarte, 2007).

Based on field evaluations and the results of genetic-statistical analyzes for the traits at two (height and crown diameter) and three years old (visually estimated biomass, weighed biomass and thick branch mass), it is recommended to continue evaluating these experiments in the coming years. These considerations are also based on the evaluation of feasibility of early selection for yerba mate performed by Wendling et al. (2018). In this case, early selection is effective at 6.5 years for the trait commercial biomass of leaves and branches smaller than $7 \mathrm{~mm}$. These results were obtained in an open pollinated yerba mate test, in the environmental conditions of Ivaí, PR and, in evaluations at ages 2.5; 4.5; 6.5 and 18.7 years. From this population, 10 of the 55 progenies were evaluated in the present study in Santa Catarina. These results emphasize the need for a longer evaluation period for both yerba mate experiments before selecting superior trees, either for use as parent trees for improved seed production or for cloning, in addition to estimating genetic correlations between traits and evaluating possible future uses of the selection index. Expanding the evaluation period will also help clarify the repeatability of yerba mate plant production during several harvests (Sturion \& Resende, 2010).

With the consolidation of clonal forestry of yerba mate (Stuepp et al., 2018), it will be possible to clone selected individuals in the future and confirm their genetic superiority through clonal tests in various contrasting environments. Additionally, parent trees may also be selected for improved seed production, either for commercial use or within breeding programs. Maximizing genetic gain is one of the most important objectives of plant breeding programs (Resende \& Barbosa, 2005). In this sense, selecting individuals for vegetative propagation is a more effective strategy and leads to greater gains than sexual propagation, since all genetic variance is captured and passed on to the offspring (Resende \& Barbosa, 2005).

Beyond its traditional uses in beverages such as chimarrão, tererê and teas, the consumption of yerba mate has also been stimulated by the presence of biocompounds, mainly methylxanthines and phenolic compounds (Cardozo Júnior et al., 2010; Bracesco, 2019), that are present in high concentrations in its leaves. These compounds have been studied in different regions of the world and have several beneficial effects on human health. Research reports effects such as antioxidant and antiinflammatory (Bracesco, 2019; Tate et al., 2020), controlling obesity (Kim et al., 2015), and reducing heart problems and brain disorders (González Arbeláez et al., 2016; Gerke et al., 2017). However, the concentration of these components in yerba mate may vary depending on the genotype, origin, time of the year in which the harvest is performed, the way leaves are processed, among other environmental conditions (Cardozo Júnior et al., 2010; Butiuk et al., 2016).

The search to combine productivity and sensory quality traits in yerba mate products has been intense. Thus, in addition to evaluating the traits related to yerba mate productivity considered in this publication, traits related to the quality of yerba mate, i.e., chemical properties such as caffeine, theobromine and antioxidant content, should also be considered. Such genetic materials could greatly contribute to the development of new products.

In addition to the future selection of better parent trees for breeding, improved seed production, and cloning, the importance of conserving the genetic variability of this germplasm already in a considerable stage of breeding is undeniable. 


\section{Conclusion}

There is genetic variability in the open pollinated yerba mate progenies evaluated in South America (Santa Catarina), with possible gains for future selection of the best parent trees for improved seed production and for cloning.

Continued harvest evaluations should provide greater reliability and safety in selecting the best trees.

The selection of genetically superior individuals, whether for the formation of seed orchards or clones, results in significant improvements in productivity gains, adaptation, resistance for the western region of Santa Catarina.

\section{Acknowledgments}

We thank the National Council for Scientific Development (CNPq), for financing this research and the National Forest (Flona) of Chapecó, for permission to use the experiment area in the Guatambu municipality.

\section{References}

Bracesco, N. (2019). Ilex Paraguariensis as a healthy food supplement for the future world. Biomedical Journal of Scientific \& Technical Research 16:1182111823 .

Butiuk, A. P., Martos, M. A., Adachi, O., \& Hours, R. (2016). Study of the chlorogenic acid content in yerba mate (Ilex paraguariensis St. Hil.): effect of plant fraction, processing step and harvesting season. Journal of Applied Research on Medicinal and Aromatic Plants 3:27-33.

Cardozo Júnior, E. L., Donaduzzi, C. M., Ferrarese-Filho, O., Friedrich, J. C., Gonela, A., \& Sturion, J. A. (2010). Análise genética quantitativa de metilxantinas e compostos fenólicos em progênies de erva-mate. Pesquisa Agropecuária Brasileira 45:171-177.

Climate-data.org. Clima: Municípios Santa Catarina. (2020). https://pt.climate-data.org/america-do-sul/brasil/rio-grande-do-sul/santa-catarina-317074

Gerke, I. B. B., Hamerski, F., Scheer, A. P., \& Silva, V. R. (2017). Clarification of crude extract of yerba mate (Ilex paraguariensis) by membrane processes: analysis of fouling and loss of bioactive compounds. Food and bioproducts processing 102:204-212.

González Arbeláez, L. F., Fantinelli, J. C., Pardo, A. C., Caldiz, C. I., Ríos, J. L., Schinella, G. R., \& Mosca, S. M. (2016). Effect of an Ilex paraguariensis (yerba mate) extract on infarct size in isolated rat hearts: the mechanisms involved. Food \& function 7:816-824.

IBGE. SIDRA: produção agrícola municipal - culturas temporárias e permanentes. (2018). https://sidra.ibge.gov.br/tabela/5457\#resultado

Kim, S. Y., Oh, M. R., Kim, M. G., Chae, H. J., \& Chae, S. W. (2015). Anti-obesity effects of yerba mate (Ilex Paraguariensis): a randomized, double-blind, placebo-controlled clinical trial. BMC Complementary and Alternative Medicine 15:1-8.

Lopes, B. G., Faria, G. A., Maltoni, K. L., Rocha, P. S., Peixoto, A. P. B., Oliveira, T. A. D., \& Felizardo, L. M. (2021). Classification of the coefficient of variation for experiments with eucalyptus seedlings in greenhouse. Revista Ciência Agronômica, 52: e20207587.

Malikouski, R. G., Peixoto, M. A., Morais, A. L. D., Elizeu, A. M., Rocha, J. R. D. A. S. D. C., Zucoloto, M., \& Bhering, L. L. (2021). Repeatability coefficient estimates and optimum number of harvests in graft/rootstock combinations for'tahiti'acid lime. Acta Scientiarum. Agronomy, 43 : e51541.

Paiva, D. I., Cascales, J., Rosetti, M. E. N., Scherer, R. A., Gauchat, M. E., \& Gottlieb, A. (2020). Unraveling the genetic complexity of a cultivated breeding population of "yerba mate" (Ilex paraguariensis St. Hil.). Anais da Academia Brasileira de Ciências 92:e20190113.

Pfleger, P., Cassol, P. C., \& Mafra, A. L. (2017). Substâncias húmicas em cambissolo sob vegetação natural e plantios de Pinus em diferentes idades. Ciência Florestal 27:807-817.

Resende, M. D. V. (2016). Software Selegen-REML/BLUP: a useful tool for plant breeding. Crop Breeding and Applied Biotechnology 16:330-339.

Resende, M. D. V., \& Barbosa, M. H. P. (2005). Melhoramento genético de plantas de propagação assexuada. Colombo: Embrapa Florestas.

Resende, M. D. V., \& Duarte, J. B. (2007). Precisão e controle de qualidade em experimentos de avaliação de cultivares. Pesquisa Agropecuária Tropical $37: 182194$

Santin, D., \& Wendling, I. (2017). Calagem e adubação para as principais espécies florestais cultivadas no Estado do Paraná: erva-mate. In: Volnei Pauletti, Antônio C. V. Motta. (Ed.). Manual de adubação e calagem para o Estado do Paraná. Curitiba: Sociedade Brasileira de Ciência do Solo.

Srivastava, P., Singh, R., Bhadouria, R., Tripathi, S., Singh, H., \& Raghubanshi, A. S. (2019). Understanding soil aggregate dynamics and its relation with land use and climate change. In: Climate Change and Agricultural Ecosystems, p. 331-354.

Stuepp, C. A., Wendling, I., Xavier, A., \& Zuffellato-Ribas, K. C. (2018). Vegetative propagation and application of clonal forestry in Brazilian native tree species. Pesquisa Agropecuária Brasileira 53:985-1002.

Sturion, J. A., \& Resende, M. D. V. (2010). Melhoramento genético da erva-mate. Embrapa Florestas. 
Research, Society and Development, v. 11, n. 3, e1611326083, 2022 (CC BY 4.0) | ISSN 2525-3409 | DOI: http://dx.doi.org/10.33448/rsd-v11i3.26083

Sturion, J. A., Stuepp, C. A., \& Wendling, I. (2017). Genetic parameters estimates and visual selection for leaves production in Ilex paraguariensis. Bragantia $76: 492-500$

Tate, O. S., Marazita, M. C., Marquioni-Ramella, M. D., \& Suburo, A. M. (2020). Ilex paraguariensis extracts and its polyphenols prevent oxidative damage and senescence of human retinal pigment epithelium cells. Journal of Functional Foods 67:103833.

Teixeira, D. H. L., Gonçalves, F. M. A., Nunes, J. A. R., Sobrinho, F. S., Benites, F. R. G., \& Das Graças Dias, K. O. (2020). Visual selection of Urochloa ruziziensis genotypes for green biomass yield. Acta Scientiarum Agronomy 42, e42444-e42444.

Wendling, I., Sturion, J. A., Stuepp, C. A., Reis, C. A. F., Ramalho, M. A. P., \& Resende, M. D. V. (2018). Early selection and classification of yerba mate progênies. Pesquisa Agropecuária Brasileira 53:279-286.

Wendling, I., Sturion, J. A., Reis, C. A. F., Stuepp, C. A., \& Peña, M. L. P. (2016). Indirect and expedite assessment of Ilex paraguariensis commercial yield. Cerne 22:241-248. 